\title{
Transitivity and the narrator's role in selected TRC testimonies
}

\author{
Zannie Bock and Paul Duncan \\ Department of Linguistics, University of the Western Cape, Private Bag X17, \\ Bellville, 7353, South Africa. E-mail: zbock@uwc.ac.za and pduncan@uwc.ac.za
}

\section{Introduction}

This paper seeks to explore how two different narrators at a hearing of South Africa's Truth and Reconciliation Commission (TRC) represent the same set of events. With the use of analytical concepts and frameworks drawn from Systemic Functional Linguistics, we show how the different narrators' roles and perspectives on the events shape their choice of genre and their construal of experience. The narrators in question are Mr Colin De Souza, a young activist from Bonteheuwel, and his mother, Mrs Dorothy De Souza. Both describe events in the 1980s when Mr De Souza and his family suffered at the hands of the then Security Branch of the South African Police Force.

\section{Background and context}

The TRC was established as a way of dealing with South Africa's past and of promoting national unity and reconciliation. It was founded on the belief that in order to build national unity and reconciliation, it should establish "as complete a picture as possible" of the injustices committed in the past (Truth and Reconciliation of South Africa Report, Vol. 1. 1998:104). At the same time, it was hoped that the work of the TRC would enable victims of human rights abuses in South Africa to "become more visible and more valuable citizens through the public recognition and official acknowledgement of their experiences" and that 
"those responsible for violations of human rights could also be held responsible for their actions" (Truth and Reconciliation of South Africa Report, Vol. 1. 1998:110).

Thousands of South Africans brought their stories to the TRC and these stories give detailed insight into the nature of oppression that people suffered under apartheid between 1 March 1960 and 10 May 1994, the dates covering the period of the TRC mandate. Approximately one tenth of the 22000 testimonies received was selected by the TRC as a representative sample of gross violations of human rights and was told at public hearings. The TRC included three kinds of hearings: those which focused on victims (the Human Rights Violations hearings); those which focused on the perpetrators (the Amnesty Hearings); and Institutional or Special Hearings which focused on either an event, such as the killing of the Gugulethu Seven, or a particular constituency, such as Women or the Business Community (Truth and Reconciliation of South Africa Report, Vol. 1. 1998). The Human Rights Violation hearings opened in East London on 15 April 1996.

In preparation for the hearings, the TRC commissioners had access to the written statements given by the witnesses to the TRC statement takers. A particular commissioner facilitated each testimony and prepared for the public hearing with the witness. On the day of the hearing, the witnesses were assisted by a briefer, who sat next to them during their testimonies and assisted them with the microphone and water, or simply gave comfort when the giving of the testimony overwhelmed the witness. The witnesses sat on the same level as the Commission panel during their testimony "to avoid any impression that they were in the dock" (Tutu 1999:83). Simultaneous interpretation was provided, as witnesses were free to tell their story in the language of their choice, and the media played an important role: "radio, TV and newspapers gave the TRC and its victim and amnesty hearings saturation coverage" (Tutu 1999:84). The hearings were taped by the South African Broadcasting Corporation (SABC).

Many different places were used for the hearings (e.g., town halls, civic centers, church halls) and most of the hearings were public. Mr Colin De Souza and his mother gave their testimonies at the Western Cape (Helderberg-Tygerberg region) Human Rights Violations hearings, which took place at the University of the Western Cape from 5-7 August 1996. 


\section{Analytical framework}

We have chosen Systemic Functional Linguistics (SFL) as an analytical framework, and focus, in particular, on the system of transitivity. We shall also be considering the genre of the testimonies. The following summary of SFL is drawn from Halliday (1994), Bloor and Bloor (1995), and Butt, Fahey, Feez, and Yallop (2000).

SFL approaches language, texts, and analysis on the basis of language being a social process and a system of meanings. The key resources available for making meaning are the lexicogrammar, or the set of patterning and wording that language consists of. This system offers the language user different choices from which (s)he selects options to create the kind of meaning that is desired and to suit the context in which the language is used. It is generally regarded as a good model of grammar for the analysis of texts (Simpson 1993).

The SFL approach recognises three main social functions (called "metafunctions") for which language is used and which are realised simultaneously in any text. Each metafunction has its own system of lexicogrammar. These main metafunctions are the interpersonal, experiential, and the textual.

The interpersonal metafunction refers to the use of language to enact social relationships and is associated with the grammatical system of mood. The experiential metafunction refers to the use of language for construing experience and is associated with the grammatical system of transitivity. The textual metafunction refers to the use of language to organise texts to fit particular contexts and is associated with the grammatical system of theme.

The testimonies of the two De Souzas are recounts of their past experience, hence our choice of the grammatical system of transitivity in analysing and interpreting these texts. The main function of the grammatical system of transitivity is to construe "the world of experience into a manageable set of PROCEss types" (Halliday 1994:106). These process types may include the following three elements:

(i) the actual process, which refers to the event or state that is described and is realised as a verbal group. The process is the core element of the system of transitivity and determines the kind and number of participants that may be associated with it. 
(ii) the participants, which refer to the people or things involved in the process. These are usually realised as nominal groups. The participants are next in terms of importance (after processes) and each clause must contain at least one participant.

(iii) the circumstances, which provide contextual information for the events or states; these are usually realised as some kind of adverbial constituent. The circumstance elements are more peripheral than the process and participant elements in the system of transitivity, and are very often optional.

Halliday identifies six different process types for English. He argues that, of these, the material, mental, and relational processes are the major types, because

they are the cornerstones of the grammar in its guise as a theory of experience, they present three distinct kinds of structural configuration, and they account for the majority of all clauses in a text ... (Halliday 1994:138)

The behavioural, verbal, and existential processes, Halliday (1994:138) suggests, are the subsidiary types. They are located at the boundaries of the three major ones and share characteristics with them. Behavioural processes are located between material and mental processes; verbal processes are positioned between mental and relational processes; and existential processes are located between the relational and material processes.

Material processes - or processes of doing - are said to be concrete doings of the material world that can be perceived. They enact "doing" and "happening", and the main (inherent) participant is the Actor. Others participants may include a Goal, Beneficiary, or Range.

Mental processes - or processes of sensing - "encode the inner world of cognition, perception, inclination, or liking/disliking (known as affect)" (Butt et al. 2000:55). The main participant is the Senser and what is sensed is called the "Phenomenon".

Relational processes - or processes of being - are processes which relate a participant either to an identity or to an attribute, and are of two main types: relational attributive and relational identifying processes. In relational attributive clauses, the main participant is the Carrier and 
the characteristic assigned to the Carrier is the Attribute. In relational identifying clauses, the main participant is the Identified and the identity assigned to the Identified is the Identifier.

Halliday describes behavioural processes as sharing characteristics of both material and mental processes, which are said to be typically "processes of physiological and psychological behaviour" (Halliday 1994:139). The main participant is the Behaver.

Verbal processes are processes that enact saying. The main participant is the Sayer, and other participants may include a Recipient and Verbiage. What is said is often realised as a separate clause, called the "Projected Clause".

Existential processes merely construe a participant that exists or an event that happens. There is only one participant, called the "Existent".

Transitivity, then, as the above descriptions show, is concerned with configurations of processes and accompanying participants and circumstances. Differences in process type often also result in differences in transitivity, with each different process type being associated with different functional participant roles. Furthermore, choices in transitivity patterns reveal the speaker's way of construing experience.

\section{Genre}

Pioneering work on genre from an SFL perspective was conducted by Hasan in her account of genre in Language, context and text, co-authored with Halliday and first published in 1985. Other theorists working within the same tradition have developed and extended her ideas, particularly in relation to the genres of everyday life and of schooling. The following account of genre draws on Hasan (Halliday and Hasan 1989), Eggins (1994), Eggins and Slade (1997), Martin and Plum (1997), and Martin and Rose (2003).

Martin and Rose (2003:7-8) define genre as follows:

For us a genre is a staged, goal oriented social process. Social because we participate in genres with other people; goal oriented because we use genres to get things done; staged because it usually takes us a few steps to reach our goals. 
Genres act as general frameworks or blueprints for interactions of particular types. These frameworks, which are culture-specific, are adaptable to the many specific contexts in which they are used. This adaptation or realisation is mediated through the register of a text which "fills in the details" of the general framework.

Eggins (1994) outlines two concepts for the analysis of genre: the 'schematic structure' of a text and its 'realisational patterns'. The schematic structure is the staged, step-by-step organisation of a genre which is established through social convention. The realisation patterns are the ways in which meaning is encoded or expressed (the lexicogrammatical choices). Eggins argues that the boundaries between the stages should be identified through a combination of functional analysis and the analysis of realisation patterns. In other words, each stage must fulfil a separate function in relation to the function of the text as a whole, and each stage will be characterised by its own distinctive lexicogrammatical patterns. She points out that realisation patterns differ, not only across schematic stages within a genre, but also across genres and registers. Within these broad stages, additional shorter phases may be identified if the text requires it (Eggins 1994:48).

SFL researchers have done a great deal of work on describing the range of genres in everyday life. Martin and Plum (1997) acknowledge their debt to Labov and Waletsky (1967) and Labov (1972)'s pioneering work on the description of narrative genre, but critically question whether the latter's narrative framework is suitable for all stories. Based on data collected by Plum, they propose, in addition to narrative, three additional kinds of story-telling genre: anecdotes, exemplums, and recounts. Space does not allow a full discussion of each kind of genre, so only narratives and exemplums will be reviewed, as they are relevant to this paper.

In a narrative, the protagonists - who may be powerful or powerless, acting alone or with others - face a series of problematic experiences which culminate in a crisis which is explicitly resolved by the actions of the protagonists. Thus the narrative moves through a series of Complicating Actions towards an end point or Resolution of that crisis. The Evaluation stage provides a break between the Complication and Resolution stages and frequently reveals the narrator's attitude towards the events. The narrative may be opened with an statement or Abstract, which introduces the story in some way, and an Orientation, which 
introduces the characters and setting for the narrative. A narrative may end with a Coda, the narrator's way of signaling that the story is finished.

Compared with the narrative, the crisis in an exemplum is not explicitly resolved. The story culminates in the judgment or moral point being made. In the Incident stage, the story consists of a series of temporally sequenced events where the focus is on the significance of the events, their interpretation, and what they illustrate, rather than on their problematic nature. In the Interpretation, evaluative comments which give a moral interpretation or judgment of the incident are made. These comments relate the incident to a broader cultural context beyond the immediate context of the text and make a moral point of some sort. Not all stages are obligatory for a genre. For example, the Abstract, Orientation, and Coda stages are optional. Some stages, such as Complicating Action and Incident, may be iterative or recurring.

It should also be noted that many texts consist of a number of genre realised simultaneously or embedded one within the other. Martin and Rose (2003:209) refer to the overarching genre as the "macro-genre". For the purposes of this project, it is worth bearing in mind that the TRC testimonies may present complex actualisations of a combination of genre.

\section{Methodology}

We obtained our data from the TRC's official website on which all transcribed testimonies are published, but also checked this record against the SABC's audiovisual record of the same testimony. First Mr Colin De Souza (CDS), then his mother, speak during their joint testimony, and CDS answers some additional questions from commissioners at the end. Both give their testimonies in English. The entire joint testimony, from the opening words by the Chairperson, and including the questions from the Commissioners, takes a full hour. We selected 10 minutes of audio-recording from the end of CDS's testimony, which is approximately 36 minutes in total. We analysed his mother's entire testimony which is 8:30 minutes long.

The next step in our analysis involved dividing the text into individual clauses, making an experiential analysis of the clauses. This involved looking at elements of transitivity that were present (mainly processes and the participants preceding the process). For each of the two 
texts, we identified the main participants (those occurring most often) and then determined the range of process types for which they functioned as the main participant.

We also attempted to classify the text as one of the story-telling genre and to identify the different stages in the genre. In the analysis which follows, we argue that CDS's testimony most closely resembles that of a narrative and Mrs De Souza's testimony that of an exemplum.

We are aware that there are a number of features of these texts that we have not considered for example, the role of intonation and gesture, the ways in which participants are named, the use of marked tenses, the use of markers such as you know and I think, and the participants following each process. Space does not allow a thorough examination of these features.

\section{Analysis of the testimonies}

We consider first CDS's testimony and then that of his mother. For each witness, we give first a summary of their full testimonies to provide contextual information, followed by, in CDS's case, an analysis of the generic structure of the selected extract. We then present short excerpts from the extracts to illustrate how we analysed the texts. Hereafter, we present the quantitative results of the transitivity analysis for the two extracts referred to in section 5 above.

\subsection{Colin De Souza's testimony}

CDS was recruited by Mkhonto weSizwe (MK) at the age of 15 and became part of the Bonteheuwel Military Wing, together with other activists, among whom were Ashley Kriel, Anton Fransch, Muhammad Ferhelst, and Andrew November.

CDS's complete (36 minute) testimony includes several chunks, each one initiated by a question from the Commissioner (Dr Orr) who was facilitating the testimony. CDS recounts how he was first arrested in October 1987, imprisoned, interrogated, and severely tortured. He was eventually released into the custody of his parents. On 16 June 1988, he was arrested for the second time, and, once again, interrogated and beaten. When he was finally released a few months later, the police warned him that they were going to kill him. And, indeed, that same night, a group of activists arrived at his parent's home to kill him, as the police had spread rumours in the community that he was an informer. He then went into hiding, as he was in 
danger from both the police and some members of the community, and, subsequently, in January 1989, he decided to leave the country.

The extract for analysis details this episode from his story, which is described as a wild car chase across the Cape Flats culminating in a manhunt for him throughout the Western Cape, and eventually ending in his arrest at his grandmother's house in Bonteheuwel. This time, he was sentenced to two years imprisonment, and he was released under one of the indemnities in 1990. In response to a Commissioner's question, he tells of the physical and psychological damage he experienced and how he continues to suffer what he says doctors describe as a "general body malaise" or "a condition of the body that is overtired and ... can't stand the stress any more". He also adds that his father and his girlfriend were badly hurt by the police as well: his father was severely assaulted and his girlfriend was forced to abort their unborn child.

CDS gives a highly dramatised performance. His narration is fluent and animated, and he uses a lot of hand gestures to show the movements of the cars, the shooting, the bullets flying overhead, and his actions as he outwitted and outmaneuvered the police. He tells his story with a certain degree of pride for the way in which he evaded the police and withstood the pressures of torture once arrested. The most notable feature of his narrative is the way he ascribes agency to himself and to the police, as the two main protagonists of his narrative; through our analysis of the generic structure and transitivity patterns of his testimony, we try to demonstrate just how this agency is construed.

His testimony follows a typical narrative structure, with a series of Complicating Actions each culminating in a crisis, over which CDS, as the main protagonist, generally depicts himself as triumphing, until his arrest by the Murder and Robbery Squad. The extract for analysis recounts a dramatic car chase across the Cape Flats, beginning at the airport and ending up in Strandfontein, followed by a chase on foot through the dunes of Strandfontein, and beyond. It can be viewed as a single narrative, consisting of a number of mini-narratives, some with several complicating actions (listed as subdivisions of the mini-narrative), an outline of which follows:

1. Evading the police at the airport 
2. The car chase across the Cape Flats

2.1 Being chased through Old Crossroads/KTC

2.2 Being chased through Mandalay/Mitchell's Plain

2.3 Being shot at by the police

2.4 Further shooting by the police

2.5 Strategising how to evade the police in a bullet-ridden car

2.6 Driving into Strandfontein in a car with no brakes

2.7 Escaping over a wall

3. The chase on foot in Strandfontein

3.1 Using guerrilla tactics to outwit the police

3.2 Hiding from the manhunt in Strandfontein

4. Seeking help from the Muslim lady

4.1 Asking for help

4.2 Slipping through the police cordon

4.3 Disguised as a New Apostolic church-goer

5. On the run

5.1 Running from the police in Heideveld

5.2 Hiding at the priest's house

5.3 Being arrested in Bonteheuwel

The reason why we have described this extract as a narrative consisting of a series of mininarratives is that each is resolved by some action of CDS (or his father), which results in him outwitting the police, as illustrated by the following resolution clauses from the first four mini-narratives:

1. and we drove past them

2. and I jumped over the wall

3. and I stayed there underneath the bushes the whole night

4. and I drove out - drove out of Mitchell's Plain to the Town Centre 
The final mini-narrative ends quite differently, as the agency shifts to the police and as the full narrative is resolved by his arrest and ultimate loss of agency:

5. and they arrest me

The foregrounding of CDS and his agency is further reflected in the transitivity choices in his testimony. Below is an example of one of the mini-narratives from CDS's testimony. In it, the main participants are highlighted (in bold) and the processes are in bold and underlined. The process type is also indicated at the end of each clause (MAT=material, EXIST=existential, $\mathrm{MEN}=$ =mental, $\mathrm{BEH}=$ behavioural, $\mathrm{VERB}=$ verbal, $\mathrm{REL}=$ relational):

\section{EXTRACT 1 (Mini-narrative 2: The car chase across the Cape Flats)}

\section{Orientation}

and at that time Strydom and Attie and some other Security cops, they drove past us, next to us with a maroon Toyota Corolla MAT and they were like waving with their guns to us, like pull down, pull down

and I was just waving my hand to them like saying goodbye

and they were chasing us, right through Old Crossroads

and when they chased us through Old Crossroads

there were a whole convoy of Security cops, cars and vehicles,

\section{$4 \times 4$ vehicles}

EXIST

and apparently that time there was MK people inside KTC that opened fire on them

EXIST

\section{Resolution}

and they lost us for a few moments

This extract typifies the way in which CDS portrays himself throughout his narrative, one comprising mainly material processes with two main participants as Actors - CDS himself and the police. The sudden change from material to existential process at the end of the 
Complicating Action signals the end of this phase of the mini-narrative and prepares for the onset of the Resolution.

In extract 2 below, the pattern referred to above continues as CDS continues to outwit the police. Here a number of mental processes indicate his mental ability to outmaneuver them as well.

\section{EXTRACT 2 (Mini-narrative 3: Chase on foot in Strandfontein)}

\section{Orientation}

And they were chasing after me in the hills there in Strandfontein

\section{Complicating action 3.1}

but to my advantage, $\mathbf{I}$ had combat boots on

REL

now I didn't sink in the sand

but they sank

because they had all tackies

REL

they were prepared to - prepared to catch me

REL

but I was very fast on my feet

REL

and I know if I - of my past experience of running for them

and of guerilla experience

MEN

I knew if I am going to run deep into this bush these people

would catch up with me

MEN

So I decided I would use the half moon formation ...

MEN

Our quantitative analysis of the transitivity patterns from the 10 minutes of audio-recording reveals the following: The extract contains 166 individual dependent and independent clauses. The main participants are CDS as an individual participant, the De Souza family - consisting of CDS; his girlfriend, who would later become his wife; and Mr De Souza Snr - the latter as an individual participant, and the police as both individual and collective participants. All these participants together are involved in 116 of the 166 clauses. The findings are set out in groups according to the main participants. 
CDS - 58 clauses

$\begin{array}{lll}\text { Material } & - & 30 \\ \text { Verbal } & - & 6 \\ \text { Behavioural } & - & 5 \\ \text { Mental } & - & 9 \\ \text { Relational } & - & 8\end{array}$

Interestingly, there was much more variation than we expected for CDS as first participant, but the preponderance of material processes was not unexpected. CDS was pitted against the police both physically (trying to flee from them) and mentally (trying to outwit them) - hence the presence of the mental processes. The six verbal processes derive from the verbal advice he gave to his father (while the latter was driving) and from the occasions he approached others for assistance in avoiding the police.

We (CDS, CDS's girlfriend, and Mr De Souza Snr) - 18 clauses

Material $\quad-\quad 15$

Verbal $\quad-0$

Behavioural $\quad-\quad 0$

Mental _ - 0

Relational $\quad-\quad 3$

The 15 material clauses here are mainly ones that construe the family's attempt to flee from the police during the car chase.

Mr De Souza Snr - 3 clauses

$\begin{array}{lll}\text { Material } & - & 2 \\ \text { Verbal } & - & 0 \\ \text { Behavioural } & - & 0 \\ \text { Mental } & - & 1 \\ \text { Relational } & - & 0\end{array}$


Mr De Souza Snr features in relatively few clauses in which he occurs as an individual participant. CDS's mother does not feature in his testimony at all.

\section{The police (the security cops, they, the dog unit, named individuals, etc.) - 37 clauses}

$\begin{array}{lll}\text { Material } & - & 28 \\ \text { Verbal } & - & 1 \\ \text { Behavioural } & - & 0 \\ \text { Mental } & - & 4 \\ \text { Relational } & - & 4\end{array}$

The high number of material processes in proportion to the others is hardly surprising and is self-explanatory: CDS construes the police as active participants bent on detaining him and denying him his agency.

\subsection{Mrs De Souza's testimony}

Mrs Dorothy De Souza's testimony covers two of the incidents mentioned by CDS, namely how the family was harassed by the police on the night before CDS's second court case, and how the police chased the family (parents and two young children) in their car that same night when, in fear, they left their house to find a safe place to sleep. She also mentions the incident referred to by CDS when the activists came to kill him, and speaks of how the family was ostracised by the community. She tells of the strain on the family, of how her husband lost his job because of their frequent court visits, of how sad she felt when her son was sent to prison (to "maximum security with rapists, murderers") for two years, and of the effect this has had on him and his four year old son.

We have analysed Mrs De Souza's testimony as an exemplum in which she recounts a number of disturbing Incidents interspersed with Interpretation. The focus of the story-telling is on the injustice of the police actions and the suffering that these events have caused, not on how they were resolved.

Her transitivity choices contrast with those of CDS, as illustrated in the extract below, the final Incident in her story: 


\section{EXTRACT 3}

\section{Incident 6}

and eventually Colin came out

MAT

but when he came out of prison

MAT

he weren't a boy any more,

REL

of course he was with evil people inside.

REL

\section{Interpretation}

And today we $\wedge$ ( $\underline{\text { are }})$ still trying to support Colin as a family

BEH

which is very hard

REL

because we're not medical doctors,

REL

he's not every day the same.

REL

Frustration builds up in him,

he's got a little boy of four years old,

REL

and I am very sorry

REL

because I don't know

MEN

how I am going to tell his child

VERB

why his daddy isn't working

and why his daddy's got this ways and all that.

REL

So it's really spoilt our whole family and another future

generation to come,

MAT

because Colin is also going to grow - his son is going to grow up

BEH

and it's going to affect him,

MEN

because he's not with his dad.

REL

\section{Coda}

So that's my story.

REL

Mrs De Souza's extract contains CDS as the main participant in seven clauses, three as Actor and four as Participant in different kinds of relational clauses depicting some of his important characteristics. This is typical of her full testimony, in which she frequently describes not only what her son is doing, but also his characteristics. 
The Interpretation is fairly lengthy (15 clauses) and reflects Mrs De Souza's concern for her son and her construal of how the De Souza family has been affected by his ordeals.

The Coda brings finality to her narrative, having as main participant the demonstrative proform that, which refers to the entire preceding narrative. The final process is relational and the final proform, that, has as Attribute her recall and construal of the experiences of her son and the rest of her family, largely at the hands of the police.

The quantitative analysis of the transitivity patterns from Mrs De Souza's testimony reveals the following: It consists of 190 dependent and independent clauses. The main participants in 126 of the 190 clauses are Mrs De Souza herself as individual participant, Mr De Souza Snr, the De Souza family at various points (parents and two younger children), CDS as individual participant, and the police as both individual and collective participants. Below is a summary of each of the main participants as well as the different process types they precede.

\section{Mrs De Souza - 35 clauses}

$\begin{array}{lll}\text { Material } & - & 1 \\ \text { Verbal } & - & 6 \\ \text { Behavioural } & - & 7 \\ \text { Mental } & - & 13 \\ \text { Relational } & - & 8\end{array}$

Clauses in which Mrs De Souza is the main participant clearly indicate her lack of direct involvement in events revolving around concrete material happenings in the external world. Her construal of her role in the family ordeal largely seems to be that of a participant in mainly physiological, psychological, and mental processes.

\section{De Souza family - 39 clauses}

$\begin{array}{lll}\text { Material } & - & 16 \\ \text { Verbal } & - & 1 \\ \text { Behavioural } & - & 6 \\ \text { Mental } & - & 8\end{array}$


Relational

8

Mrs De Souza's involvement and participation in the material happenings seem to come to the fore through the preponderance of material processes with the collective family (comprising herself, her husband and her younger children) as the first participant.

\section{Mr De Souza Snr - 4 clauses}

$\begin{array}{lll}\text { Material } & - & 3 \\ \text { Verbal } & - & 1 \\ \text { Behavioural } & - & 0 \\ \text { Mental } & - & 0 \\ \text { Relational } & - & 0\end{array}$

The striking feature of Mrs De Souza's representation of her husband is the low number of clauses in which he appears as the main participant. This pattern repeats CDS's representation of his father.

\section{CDS - 18 clauses}

$\begin{array}{lll}\text { Material } & - & 8 \\ \text { Verbal } & - & 1 \\ \text { Behavioural } & - & 0 \\ \text { Mental } & - & 1 \\ \text { Relational } & - & 8\end{array}$

Mrs De Souza's description of CDS's involvement shows an equal number of material and relational processes, indicating (i) his active role in the concrete goings-on of his activist past but also (ii) the descriptions of him (constructed by his mother) as a Carrier of different Attributes.

\section{The police (collective and individual) - 32 clauses}

$\begin{array}{lll}\text { Material } & - & 20 \\ \text { Verbal } & - & 8 \\ \text { Behavioural } & - & 0\end{array}$


$\begin{array}{lll}\text { Mental } & - & 2 \\ \text { Relational } & - & 2\end{array}$

Here, the high number of material processes shows Mrs De Souza's construal of the level of police involvement in the experiences of the De Souza family. One senior police officer is mentioned by name (also in the testimony of others) and in each case (thrice) he is the Sayer participant in Verbal process in which he only appears. This is perhaps indicative of his seniority - he was seen to be instructing or giving orders - as well as his ability to not make his involvement apparent in material goings-on of the Security Branch.

\section{Conclusion}

The different genre and transitivity patterns reflect the different positions of the two narrators in relation to the events described: CDS, the activist, was the direct target of the police action, and was frequently in the role of running from the police. This is reflected in the preponderance of material processes attributed by CDS to himself and the police, against whom he was pitted. His mother, on the other hand, as a member of his family, was more frequently in the role of worrying about her son, trying to support and protect him, and of answering questions asked by the police. Significantly, when she is the first participant (I), the preponderant process type is mental, and her use of material processes are reserved for her in conjunction with her family (we) or, predictably, for her account of police actions.

We have considered possible reasons for the way in which CDS construes his experience. Could this "appropriation of agency" be understood as an attempt to reclaim a power and agency the police were determined to deny him? To what extent is this narrative style typical of other activists who testified at the TRC? ${ }^{1}$ How do the testimonies of men and women activists compare? Or are these differences simply the result of gender difference and the way men and women talk about their experiences? ${ }^{2}$ A much bigger study of a number of different TRC narratives, told by both men and women who are both activists and family members, would be needed to answer these questions conclusively. 


\section{Notes}

1. Blommaert (2005:95), in his analysis of CDS's testimony, argues that his style of narration aligns him with "the stylistic tradition of his Military Wing subculture: that of factual event narratives from which explicit emotion or accounts of suffering are all but elided".

2. Eggins and Slade (1997:266) report on the differences between the kinds of stories that men and women tell, albeit in casual conversation and in very different contexts from those of the TRC testimonies: "The men told more stories where there was an explicit resolution, of the kind of a hero overcoming adversity. The woman told more anecdotes which involved embarrassing, humiliating or worrying situations, where the story culminated in a reaction, such as an outburst of laughter".

\section{References}

Blommaert, J. 2005. Discourse: A critical introduction. Cambridge: Cambridge University Press.

Bloor, T. and B. Bloor. 1995. The functional analysis of English: A Hallidayan approach. London: Edward Arnold.

Butt, B., R. Fahey, S. Feez, and C. Yallop. 2000. Using functional grammar: An explorer's guide. Macquarie University: National Centre for English Language Teaching and Research.

Eggins, S. 1994. An introduction to Systemic Functional Linguistics. London: Continuum.

Eggins, S. and D. Slade. 1997. Analysing casual conversation. London: Cassell.

Halliday, M.A.K. 1994. An introduction to functional grammar. $2^{\text {nd }}$ edition. London: Edward Arnold.

Halliday, M.A.K. and R. Hasan. 1989. Language, context and text. $2^{\text {nd }}$ edition.. Oxford: Oxford University Press.

Labov, W. 1972. Language in the inner city. Philadelphia: University of Pennsylvania Press.

Labov, W. and J. Waletsky. 1967. Narrative analysis: Oral versions of personal experience. In J. Helm (ed). Essays on the verbal and visual arts: Proceedings of the 1996 Annual 
Spring Meeting of the American Ethnological Society. Seattle: University of Washington Press. pp.12-44.

Martin, J.R. and G.A. Plum. 1997. Construing experience: Some story genres. Journal of Narrative and Life History 7: 299-308.

Martin, J.R. and D. Rose. 2003. Working with discourse: Meaning beyond the clause. London: Continuum.

SABC Video footage: TRC Helderberg-Tygerberg, 5/9/96. Tapes 2.

Simpson, P. 1993. Language, ideology and point of view. London: Routledge.

Truth and Reconciliation of South Africa Report. Volume 1. 1998. Cape Town: TRC Commission (distributed by Juta and Co Ltd).

TRC transcripts available on http://www.doj.gov.za/trc.

Tutu, D. 1999. No future without forgiveness. London: Rider. 